\title{
OPEN Shallow seamounts represent speciation islands for circumglobal yellowtail Seriola lalandi
}

\begin{abstract}
Sven Kerwath ${ }^{1,2,8 凶}$, Rouvay Roodt-Wilding ${ }^{3}$, Toufiek Samaai ${ }^{2,4}$, Henning Winker ${ }^{1}$, Wendy West ${ }^{1}$, Sheroma Surajnarayan ${ }^{5}$, Belinda Swart ${ }^{3}$, Aletta Bester-van der Merwe ${ }^{3}$, Albrecht Götz ${ }^{6}$, Stephen Lamberth ${ }^{1,7}$ \& Christopher Wilke ${ }^{1}$

Phenotypic plasticity in life-history traits in response to heterogeneous environments has been observed in a number of fishes. Conversely, genetic structure has recently been detected in even the most wide ranging pelagic teleost fish and shark species with massive dispersal potential, putting into question previous expectations of panmixia. Shallow oceanic seamounts are known aggregation sites for pelagic species, but their role in genetic structuring of widely distributed species remains poorly understood. The yellowtail kingfish (Seriola lalandi), a commercially valuable, circumglobal, epipelagic fish species occurs in two genetically distinct Southern Hemisphere populations (South Pacific and southern Africa) with low levels of gene-flow between the regions. Two shallow oceanic seamounts exist in the ocean basins around southern Africa; Vema and Walters Shoal in the Atlantic and Indian oceans, respectively. We analysed rare samples from these remote locations and from the South African continental shelf to assess genetic structure and population connectivity in S. lalandi and investigated life-history traits by comparing diet, age, growth and maturation among the three sites. The results suggest that yellowtail from South Africa and the two seamounts are genetically and phenotypically distinct. Rather than mere feeding oases, we postulate that these seamounts represent islands of breeding populations with site-specific adaptations.
\end{abstract}

Seamounts have long been known as aggregation sites for large pelagic fishes such as tuna, billfishes and sharks ${ }^{1}$. Phenotypic plasticity might explain observed differences in growth, maturation and reproduction related traits, depending on natural and fishing mortality, access to resources and environmental variation, as there has been little evidence of genetic isolation of seamount associated pelagic fish populations ${ }^{2}$, yet, recent literature has detected genetic structure in wide ranging large pelagic fishes ${ }^{3}$, questioning the current understanding of seamounts as mere feeding oases and navigation aids.

Two oceanic seamounts that extend into the photic zone are known to exist around southern African waters, Vema $\left(31^{\circ} 41^{\prime} \mathrm{S}, 8^{\circ} 20^{\prime} \mathrm{E}\right)$ in the southern Atlantic Ocean and Walters Shoal ( $\left.33^{\circ} 9^{\prime} \mathrm{S}, 43^{\circ} 49^{\prime} \mathrm{E}\right)$ in the Southern Indian Ocean (Fig. 1). Both features harbour endemic species ${ }^{4,5}$ with a pelagic propagule phase, which suggests the existence of hydrographic mechanisms for larval retention. Yet, both are also home to common, widely distributed organisms such as the yellowtail kingfish, Seriola lalandi Valenciennes, 1833 (Carangidae). Yellowtail are circumglobal predators occurring in temperate and subtropical waters. Yellowtail occur in a variety of epipelagic habitats from the surf zone to the open ocean and aggregate around isolated features such as seamounts and reef pinnacles $^{6-8}$. An important fisheries and aquaculture species throughout its distribution, aquaculture production of yellowtail in some countries generally outweighs that of wild commercial harvesting by up to $75 \%{ }^{9}$, but wild stocks continue to support fisheries such as in South Africa ${ }^{10,11}$.

\footnotetext{
${ }^{1}$ Fisheries Management, Department of Environment, Forestry and Fisheries, Private Bag X2, Vlaeberg 8018, South Africa. ${ }^{2}$ Department of Biological Sciences, University of Cape Town, Private Bag X3, Rondebosch 7701, South Africa. ${ }^{3}$ Molecular Breeding and Biodiversity Group, Department of Genetics, Stellenbosch University, Private Bag $\mathrm{X} 1$, Stellenbosch, South Africa. ${ }^{4}$ Oceans and Coasts, Department of Environment, Forestry and Fisheries, Private Bag X4390, Cape Town, Foreshore District 8001, South Africa. ${ }^{5}$ Department of Environmental Sciences, University of South Africa, PO Box 392, Unisa 003, South Africa. ${ }^{6}$ Elwandle Node, South African Environmental Observation Network (SAEON), PO Box 77000, Port Elizabeth 6031, South Africa. ${ }^{7}$ Zoology Department, Nelson Mandela Metropolitan University, Port Elizabeth 6031, South Africa. ${ }^{8}$ Department of Animal Sciences, Stellenbosch University, Private Bag X1, Stellenbosch, South Africa. ${ }^{\circledR}$ email: SvenK@daff.gov.za
} 


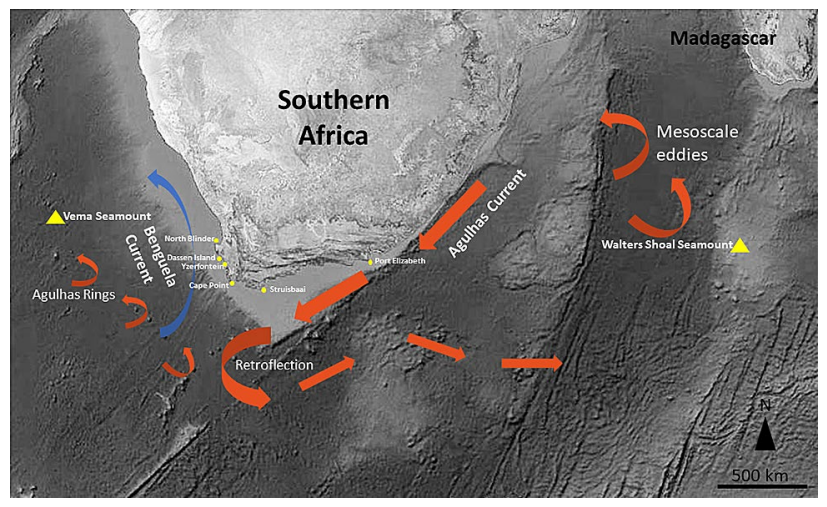

Figure 1. Map of southern Africa. The two shallow seamounts, Vema and Walters Shoal are indicated as yellow triangles, the South Africa sampling sites are indicated as yellow dots. Currents are schematised in form of arrows (red for warm, blue for cold currents). Background map created ex-novo by Dr Lauren Williams, Department of Environment, Forestry and Fisheries (DEFF), Oceans and Coasts Research, GIS Unit. Software ArcGIS version 10.3.1, licenced to DEFF.

Yellowtail are pelagic nomads ${ }^{10}$ and their movement is strongly influenced by oceanographic conditions and prey availability ${ }^{6,12,13}$. Movements of up to $2960 \mathrm{~km}$ have been reported from tagging studies ${ }^{14}$ along with some site fidelity in larger specimens at certain sites, linked to availability of food and favourable environmental conditions, providing further support for a nomadic existence ${ }^{6,15}$.

In addition to the large range of individual adult yellowtail, this species has considerable dispersal potential for eggs, larvae and juveniles. Like many pelagic species, yellowtail are broadcast spawners that produce large numbers of pelagic eggs ${ }^{16}$ during multiple spawning events within a spawning season. Spawning in the Southern Hemisphere occurs in austral summer and has been reported from offshore reefs ${ }^{6,12}$, as well as within bays ${ }^{17}$. The larvae and juveniles are often associated with flotsam, which suggests potential for dispersal through ocean currents.

Despite the global distribution and long distance dispersal potential throughout all life history stages, phylogeographic analyses suggest significant spatial population differentiation on different geographic scales based on meristics and phylogenetics ${ }^{18,19}$.

In the current study we examined the genetic structure and life history characteristics, specifically diet and growth, of yellowtail associated with the two seamounts and from the South African continental shelf. Specifically we investigated the hypotheses that (1) Vema and Walters Shoal function as aggregation and feeding points of a panmictic yellowtail population distributed around Southern Africa (Oasis hypothesis) or (2) that Vema and Walters Shoal host populations of yellowtail genetically and phenotypically differentiated from each other and from coastal populations (Island hypothesis).

\section{Results}

Microsatellite data. Genetic diversity was determined in a total of 351 individuals from three main sampling regions using genotype data generated from six microsatellite markers. Population differentiation was also successfully assessed using F-statistics, multivariate and clustering analyses.

Genetic diversity. The software MICRO-CHECKER indicated that only two loci showed evidence of null alleles (Sdu29 and SduCA4j). These markers were included in subsequent analyses due to the limited number of microsatellite markers available in this study.

The average number of alleles per locus ranged from 2 (Sdu10) to 26 (SduCA107; Table S1 in Appendix S1). Allelic richness ranged from 2 ( $S d u 10$ ) to 15.640 ( $S d u C A 107$; Table S1 in Appendix S1), and average values were comparable between sampling population. Genetic diversity statistics as per locus was similar across sampling sites in terms of observed heterozygosity (Table S1 in Appendix S1). Among loci values of average observed heterozygosity ranged from $\mathrm{Ho}=0.4167$ at locus $S d u 46$ to $\mathrm{Ho}=0.9787$ at locus $S d u C A 4 j$.

Simulations of statistical power performed in POWSIM indicated that pairwise differentiation based on all 6 microsatellites at a level of $\mathrm{F}_{\mathrm{ST}}>0.010$, was significant in $100 \%$ of the 1000 replicates for both chi-squared and Fisher's exact test (Table S3 in Appendix S1). These results suggest that samples sizes and number of loci used here were large enough to detect genetic differentiation levels $>0.010$.

Population differentiation. Overall, large genetic distances, and significant pairwise $\mathrm{F}_{\mathrm{ST}}$ values were found between sampling sites from South Africa and the two seamounts; Vema and Walters Shoal (Table 1, Table S4 in Appendix S1). This strong genetic differentiation was supported by the large and significant $G_{\text {ST }}$ and Jost $D_{\text {EST }}$ values found between the three main sampling regions (Table 2). Pairwise $\mathrm{F}_{\mathrm{ST}}$ values between the five South African sampling sites were relatively low (Table 1), with the lowest between Cape Point, Struis Bay and Port Elizabeth. The $\mathrm{F}_{\mathrm{ST}}$ values were only significant $(\mathrm{p}<0.05)$ between the two South African sampling sites North Blinder and Yzerfontein. Pairwise $\mathrm{F}_{\mathrm{ST}}$ values based on only the four loci devoid of null alleles showed a similar overall 


\begin{tabular}{|c|c|c|c|c|c|c|c|}
\hline & North Blinder & Yzerfontein & Cape Point & Struis Bay & Port Elizabeth & Walters Shoal & Vema \\
\hline North Blinder & - & $0.023^{*}$ & $0.015^{*}$ & $0.010^{*}$ & $0.018^{*}$ & $0.146^{\star}$ & $0.163^{*}$ \\
\hline Yzerfontein & & - & $0.038^{*}$ & $0.029^{*}$ & $0.026^{*}$ & $0.164^{*}$ & $0.164^{*}$ \\
\hline \begin{tabular}{|l|} 
Cape Point \\
\end{tabular} & & & - & 0.007 & 0.009 & $0.143^{*}$ & $0.151^{*}$ \\
\hline Struis Bay & & & & - & 0.005 & $0.124^{*}$ & $0.138^{*}$ \\
\hline Port Elizabeth & & & & & - & $0.138^{*}$ & $0.139^{*}$ \\
\hline Walters Shoal & & & & & & - & $0.043^{*}$ \\
\hline Vema & & & & & & & - \\
\hline
\end{tabular}

Table 1. Pairwise $\mathrm{F}_{\mathrm{ST}}(1,000$ permutations; above diagonal) values of seven Seriola lalandi populations. ${ }^{\star}$ Significant $F_{S T} p$-values $(p<0.05)$ after Bonferroni correction.

\begin{tabular}{|l|l|l|l|}
\hline & South Africa & Walters Shoal & Vema \\
\hline South Africa & - & $0.543^{*}$ & $0.577^{\star}$ \\
\hline Walters Shoal & $0.612^{\star}$ & - & $0.135^{*}$ \\
\hline Vema & $0.644^{*}$ & $0.172^{\star}$ & - \\
\hline
\end{tabular}

Table 2. Pairwise $\mathrm{G}_{\mathrm{ST}}$ (999 permutations; below diagonal) and $\mathrm{D}_{\mathrm{EST}}$ (999 permutations; above diagonal) values for the SA, Vema and Walters Shoal Seriola lalandi populations. ${ }^{\star}$ Significant $p$-values $(p<0.05)$ after Bonferroni correction.

pattern with significant values only between sampling sites from South Africa and the two seamounts; Vema and Walters Shoal (Table S2 in Appendix S1). AMOVA revealed overall significant genetic structuring between South Africa and the two seamount populations $\left(\mathrm{F}_{\mathrm{ST}}=0.131, \mathrm{p}=0.000\right)$. Most of the total genetic variance was found between individuals within populations (86.88\%) with very little variance distributed among populations within groups (1.47\%). Results of the DAPC based on the $95 \%$ confidence ellipses showed a strong separation between individuals from South Africa and those from the two seamounts, with overlap mostly between individuals of the two seamounts (Fig. 2).

Bayesian clustering analysis was used to infer the number of genetically distinct (ancestral) populations, assuming no prior information on the number of sampling locations. Based on $\Delta K$, three clusters were detected and membership assignment plots $(\mathrm{K}=3)$ indicated a clear separation between the South African, Vema and Walters Shoal seamount populations (Figure S1 in Appendix S1).

Life history. Diet. All 54 (100\%) stomach samples from Vema contained food. For the Walters Shoal specimens, only 28 (50\%) of the 56 stomachs contained food whereas in the 62 South African samples, 47 (76\%) contained food that could be partially identified.

The yellowtail diet at all three locations principally consisted of fish, crustaceans and cephalopods. In the stomachs of the Vema yellowtail, crustaceans had the highest frequency of occurrence (FO) with $81.5 \%$, followed by fish with $F O$ of $68.5 \%$ (Table S5 in Appendix S1). In the Walters Shoal yellowtail fish and crustaceans both had high $F O$ of $67.9 \%$ and $64.3 \%$, respectively.

Bony fish dominated the stomachs of the South African yellowtail with an FO of $74.19 \%$. The yellowtail stomachs from Walters Shoal featured a larger variety of crustaceans compared to the Vema sample. The most frequent crustacean in the Vema sample was an euphausiid species which occurred in $81.5 \%$ of the stomachs. With 25\%, Lysiosquilla tredecimdentata (mantis shrimp) had the highest FO in the Walters Shoal sample. Other crustacean species occurred in less than $15 \%$ of the stomachs at both seamount locations. The only crustacean group that made a significant contribution to the diet of yellowtail in South Africa were the crab megalopa larva (FO 19.35\%).

Yellowtail stomachs from Walters Shoal contained a lower variety of fish species with only three families identified, as compared to the Vema samples, which contained six different families and South Africa with four different families. No common fish species were found in yellowtail stomachs at the three locations. Cephalopods were found in $28.6 \%$ of the Walters Shoal stomach samples compared to $18.5 \%$ and $9.68 \%$ for the Vema and South African stomach samples, respectively. The cephalopods were difficult to identify even to family level, however, two families (Histioteuthidae, Ommastrephidae) from one order (Teuthida) were identified in the Vema diet while one family (Octopoteuthidae) and two orders (Octopoda, Teuthida) were found in the Walters Shoal sample. Molluscs did not feature in the Walters Shoal diet and were of negligible importance in the diet of the Vema and South African yellowtail with a $F O$ of $7.4 \%$ and $>2 \%$, respectively.

Age and growth. Yellowtail sampled at Vema displayed a broad size range from $445 \mathrm{~mm}$ FL and a weight of $1.220 \mathrm{~g}$ to $1.005 \mathrm{~mm}$ FL and a weight of $12.900 \mathrm{~g}$. The South African yellowtail ages ranged from $490 \mathrm{~mm}$ FL and a weight of $2.000 \mathrm{~g}$ to $916 \mathrm{~mm} \mathrm{FL}$ and a weight $6.550 \mathrm{~g}$. The fish sampled at Walters Shoal ranged from $521 \mathrm{~mm}$ 


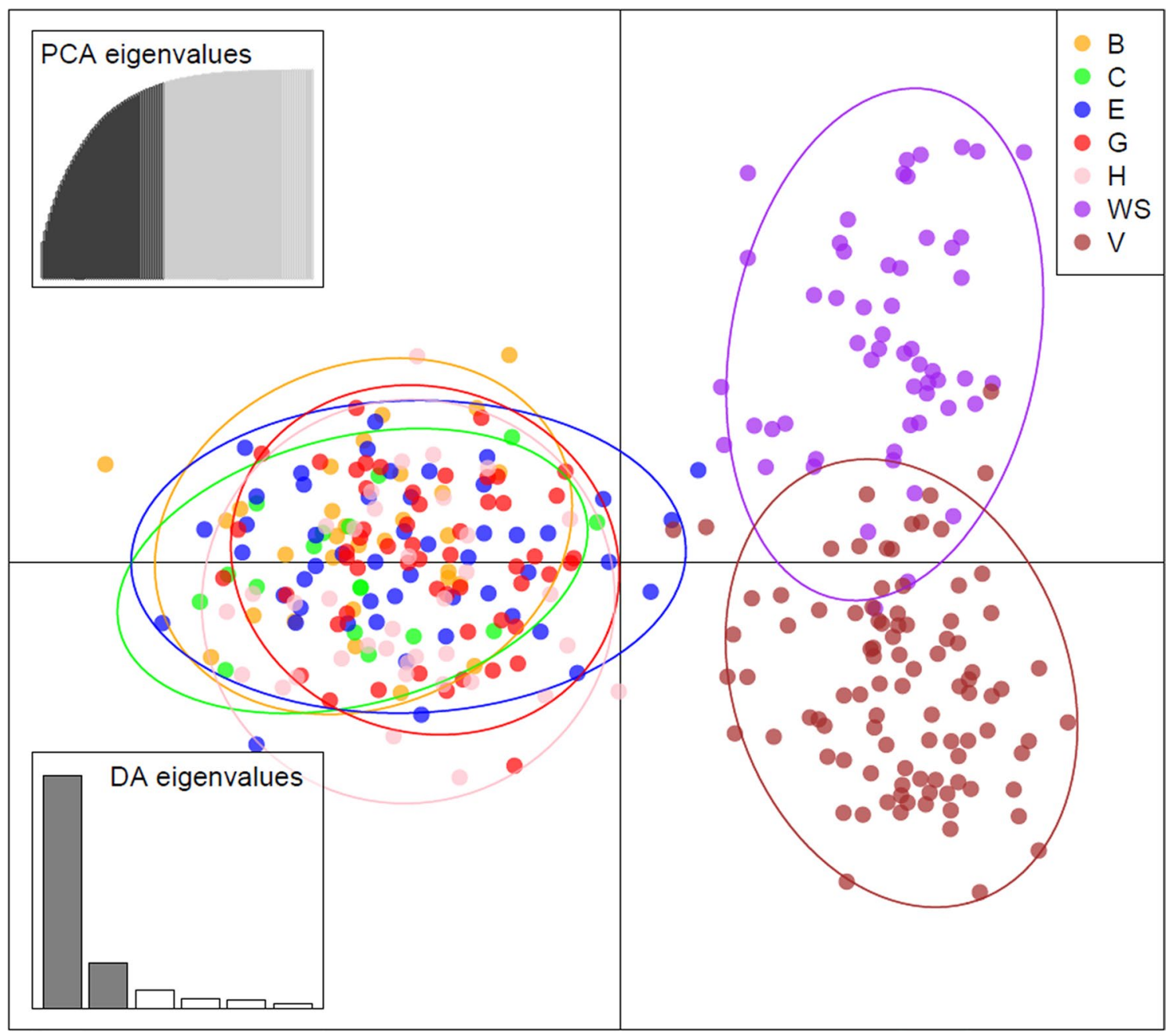

Figure 2. Discriminant analysis of principal components (DAPC) showing the principal components and $95 \%$ confidence ellipses of all Seriola lalandi samples: B-North Blinder, C-Yzerfontein, E-Cape Point, G-Struis Bay, H-Port Elizabeth. V-Vema, WS-Walters Shoal. PCA, principal component analysis; DA, discriminant analysis.

FL and a weight of $1.772 \mathrm{~g}$ to $844 \mathrm{~mm}$ FL and a weight of $6.894 \mathrm{~g}$. Length-weight relationships differed among the locations (Fig. 3a), resulting in highly significantly differences in the respective condition factors $K$ (Fig. 3b), as judged by an one-way ANOVA applied specimens of 500-700 $\mathrm{mm} F L(F=142.6, d f=178, \mathrm{p}<0.05)$. The condition factor was highest for Vema followed by South Africa and Walters Shoal.

Age readings were accepted for $83.3 \%$ of the individuals from the Vema sample, $73 \%$ of the South African specimens and $87.5 \%$ of the Walters Shoal sample, with APE and CV values of $15.5 \%$ and $14.8 \%$ (Vema), $16.2 \%$ and $21.7 \%$ (South Africa), and $10.5 \%$ and $11.5 \%$ (Walters Shoal), respectively. Age readings ranged from 2 to 7 years for all subsamples combined, but only the year classes 3 and 4 had large enough sample sizes (Vema $=31$, $\mathrm{SA}=162$, WS $=33$ ) for a meaningful comparison. The two-way ANOVA showed that there was a highly significant difference in length-at-age among the three locations $(F=20.08, d f=222, p<0.001)$ (Fig. $4 \mathrm{a})$. Three and four year old fishes were largest in South Africa, followed by Walters Shoal and Vema (Fig. 4b).

Sex ratio and gonad development. The Vema sample consisted of 54 individuals, 19 of which were males ranging from 445 to $914 \mathrm{~mm}$ fork length (FL), 25 females ranging from 452 to $1005 \mathrm{~mm}$ FL and the remainder were unidentifiable. The sex ratio of males to females was found to be 1:1.32. The number of mature females in the sample was 20 (80\%), the smallest mature females were $452 \mathrm{~mm}$ FL in both stage 2 and 3 classes while the largest mature female was recorded at 1,005 $\mathrm{mm}$ FL (stage 3 ). The number of mature males in the sample was 18 (95\%), the smallest mature male was recorded at $445 \mathrm{~mm}$ FL (stage 2) while the largest mature male was found to be $914 \mathrm{~mm}$ FL stage 3.

In the 51 South African samples, the smallest mature male was $520 \mathrm{~mm}$ FL. All males above $820 \mathrm{~mm}$ FL were mature. The smallest mature female observed in this study was $520 \mathrm{~mm}$ FL. All females above $780 \mathrm{~mm}$ FL were mature. The sex ratio of males to females was found to be $1: 1.15$. 

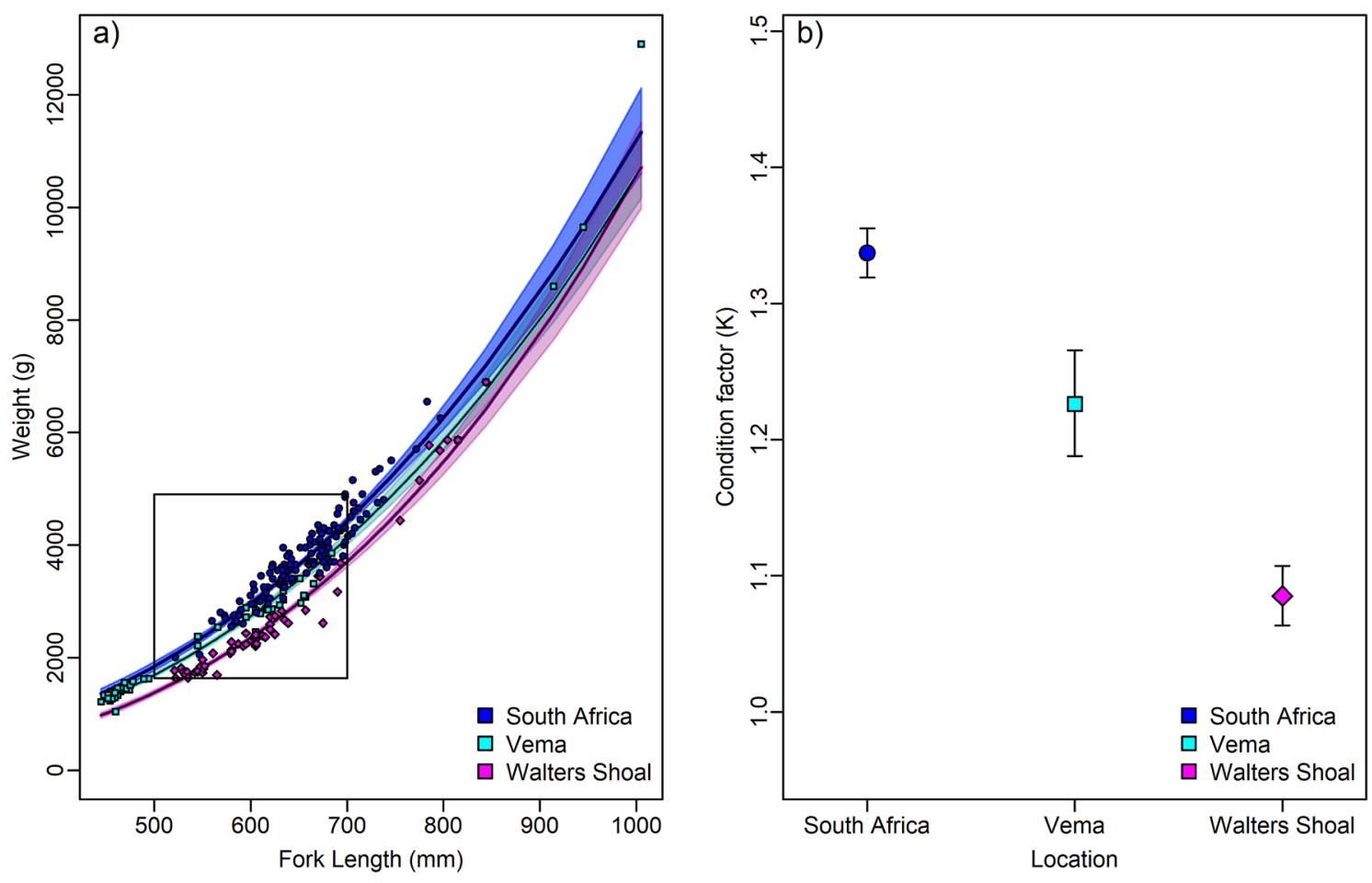

Figure 3. (a) Observed (symbols) and predicted (solid lines) length-weight relationships and (b) expected mean values of the condition factor $K$ for yellowtail from sampling localities from South Africa, Vema and Walters Shoal sampling localities. The box highlights the size classes of 500 to $700 \mathrm{~mm}$ FL fish that were well represented for each sampling localities and used calculate the condition factor. Colour coded translucent areas (a) and error bars (b) denote the 95\% confidence intervals the respective sampling locality. Differences in the colour gradients of shaded areas (a) result from overlaps in 95\% confidence areas.
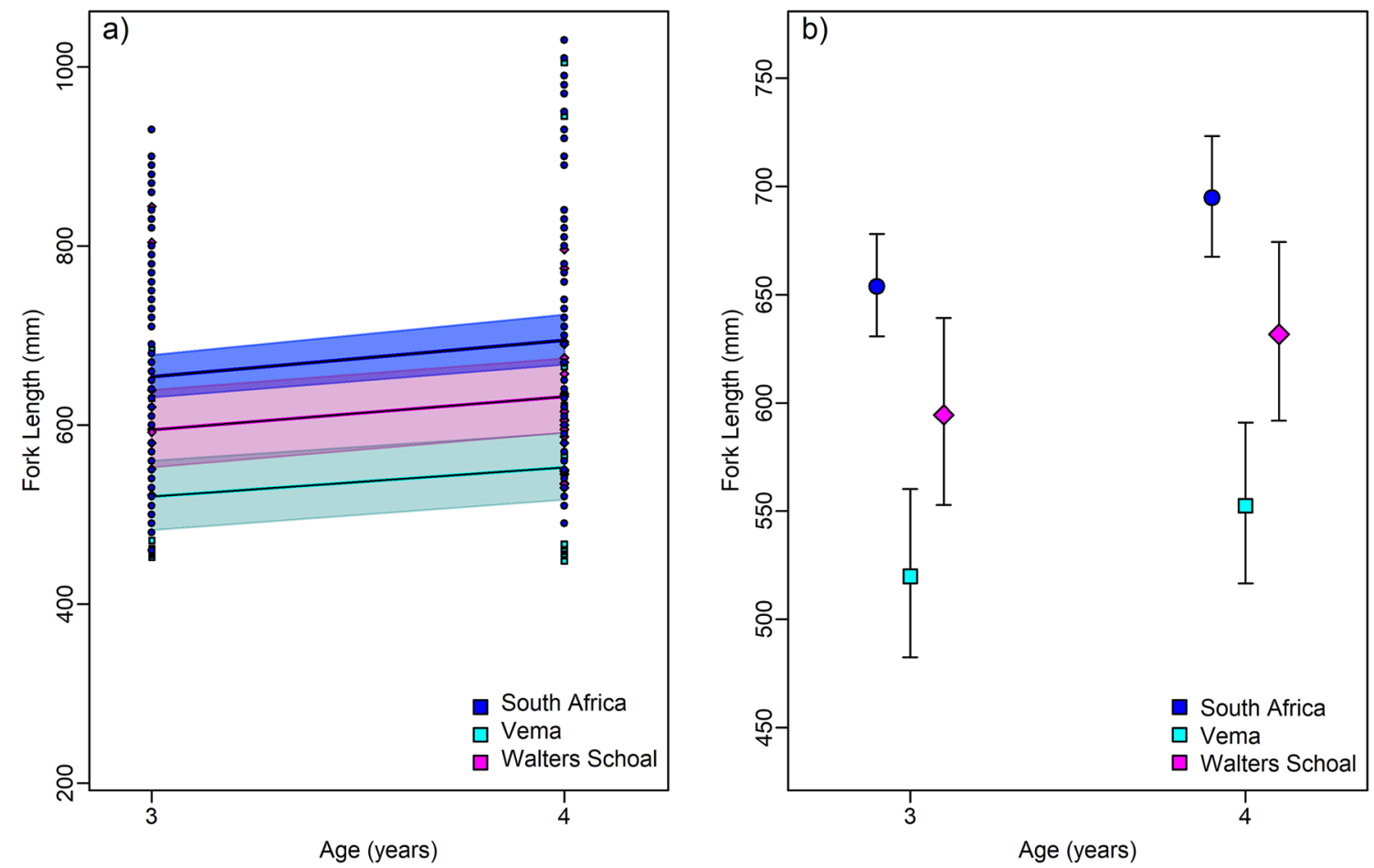

Figure 4. (a) Observed (symbols) and predicted (solid lines) lengths-at-age of Age-3 and Age-4 yellowtail from South Africa, Vema and Walters Shoal sampling localities. Coloured coded translucent areas (a) and error bars (b) denote the $95 \%$ confidence intervals the respective sampling locality. Difference in the gradients shades (a) result from overlaps in $95 \%$ confidence areas. Differences in the colour gradients of shaded areas (a) result from overlaps in $95 \%$ confidence areas. 


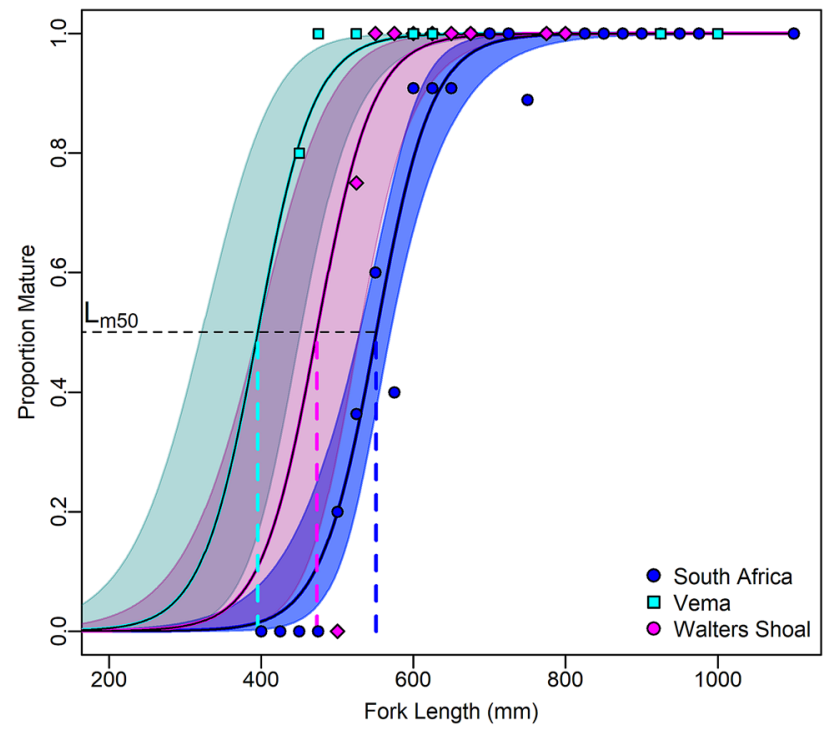

Figure 5. Logistic maturity ogives showing observed (symbols) and predicted (solid lines) -lengths-at-maturity for female yellowtail from South Africa, Vema and Walters Shoal sampling localities. Colour-coded translucent areas denote the $95 \%$ confidence intervals the respective sampling locality. Colour-code dashed lines depict the estimated lengtht-at-50\%-maturity $\left(L_{m 50}\right)$ for each locality. Differences in the colour gradients of shaded areas result from overlaps in $95 \%$ confidence areas.

Of the 56 yellowtail from Walters Shoal, 22 were males ranging from 530 to $844 \mathrm{~mm}$ FL and 34 were females ranging from 521 to $815 \mathrm{~mm}$ FL. The smallest mature female was $521 \mathrm{~mm}$ FL (stage 3) and the largest mature female was $815 \mathrm{~mm}$ FL, also stage 3 . The number of mature males in the sample was $10(45 \%)$. The smallest male was $530 \mathrm{~mm}$ FL (stage 2) and the largest male was $844 \mathrm{~mm} \mathrm{FL} \mathrm{(stage} \mathrm{2).} \mathrm{Analysis} \mathrm{of} \mathrm{deviance} \mathrm{found} \mathrm{that} \mathrm{local-}$ ity explained significant variation in female length-at-maturity $(p<0.001)$, with length-at-50\%-maturity $\left(L_{m 50}\right)$ estimated to occur significantly smaller at Vema with $395.1 \mathrm{~mm} \mathrm{FL}(p<0.001)$ and Walter Shoal with $473.2 \mathrm{~mm}$ FL $(p<0.01)$ than in South Africa with $551.2 \mathrm{~mm}$ FL (Fig. 5).

\section{Discussion}

Despite the species' movement behaviour and dispersal potential, our results revealed the following: (1) the existence of genetically and phenotypically distinct populations of yellowtail associated with the South African continental shelf and the two seamounts in the Atlantic and Indian oceans; and (2) supports the 'Island' hypothesis (seamounts are regarded as solitary islands, where speciation occurs ${ }^{20}$ ) as opposed to the 'Oasis' hypothesis ${ }^{21}$.

The microsatellite data support the existence of three genetically distinct groups of yellowtail across the sampling regions with little connectivity between South Africa and the two seamounts. This implies the three main geographic sampling regions either serve as reservoirs for larval or egg retention and/or adult individuals return to the regions where they were spawned.

Overall estimates of genetic variability were significantly different between the three main sampling regions and significant pairwise $\mathrm{F}_{\mathrm{ST}}, \mathrm{G}_{\mathrm{ST}}$ and $\mathrm{D}_{\mathrm{EST}}$ comparisons were observed between all South African sampling sites and the two seamounts. Both multivariate (DAPC) and Bayesian clustering analysis supported the existence of three distinct genetic clusters corresponding to South Africa, Walters Shoal and Vema seamount.

Marine animal populations are linked to each other via dispersal of individuals as eggs, larvae, juveniles or adults, a process known as connectivity. The extent of dispersal and connectivity is determined by several factors, including oceanographic and hydrological features as well as the reproductive strategy of the species ${ }^{22}$. Retention and dispersal of sedentary species is largely a function of passive drift of eggs and larvae, limiting connectivity between seamounts ${ }^{23,24}$. On the other hand, mobile species such as yellowtail are theoretically able to move between seamounts as juveniles and during their reproductive phase ${ }^{25}$.

A higher level of connectivity and thus gene flow was evident between the two seamounts. The passive dispersal of eggs and larvae (17 days of preflexion) and the movement of juveniles via flotsam ${ }^{26}$ could result in dispersal over hundreds of kilometers along major ocean currents, resulting in high gene flow over a large distance. Walters Shoal is occasionally swept by mesoscale eddies originating from the East Madagascar Current, one of the Agulhas Current's tributaries. The Agulhas Current flows in south-westerly direction along the edge of the continental shelf of the African continent. Near $36^{\circ} \mathrm{S}$ at the Agulhas Bank, it separates from the continental shelf and turns eastwards in an anticyclonic loop, named the Agulhas retroflection by Bang ${ }^{27}$. It then flows back into the South Indian Ocean as the Agulhas Return Current. Periodically the loop of the retroflection forms an eddy, which is ejected into the South Atlantic Ocean ${ }^{28}$. The Vema seamount is in the path of these Agulhas rings $s^{29,30}$. These oceanographic features provide a mechanism for passive transport of propagules and juveniles from Walters Shoal to Vema, bypassing the South African coastline. This would also explain some of the genetic 
admixture observed around Cape Point which is the closest 'exit point' for passively drifting objects before the uptake into the Benguela jet.

Connectivity between seamounts is a key element affecting the degree of isolation or similarity of seamount populations. Studies on the genetic population connectivity among commercially important seamount and slope fish populations have however provided varied results. Most studies report genetic homogeneity between seamount and continental and oceanic island slopes including species such as the northern Pacific pelagic armourhead (Pseudopentaceros wheeleri), the alfonsino (Beryx splendens), black oreo (Allocyttus niger), smooth oreo (Pseudocyttus maculates), orange roughy (Hoplostethus atlanticus) and offshore rockfish (Pontinus kuhlii) ${ }^{31-36}$. On the contrary, genetic heterogeneity or differentiation between seamount and continental populations has been identified in only a few species of fish, (e.g., between the continental margin of Europe, and the Azores Islands on the Mid-Atlantic Ridge in blue-mouth red fish Helicolenus dactylopterus ${ }^{37}$. Mitochondrial DNA and microsatellite analyses of black sea bream (Pagellus bogaraveo) populations between slopes of the Azores Islands in the North Atlantic revealed low to moderate (but significant) genetic differentiation with evidence for a recent bottleneck, perhaps due to the impacts of fishing ${ }^{38}$. In the patagonian toothfish (Dissostichus eleginoides), although the mitochondrial DNA marker $12 \mathrm{~S}$ rDNA failed to reveal genetic structure ${ }^{39}$, differences in microsatellite frequencies were evident between seamount and non-seamount populations.

The observed genetic differences among yellowtail are concomitant with differences in life history and diet. Albeit based on small, single sampling events, due to the difficulty of obtaining samples from such remote locations, our results suggest that the three samples differentiate by condition factor, diet, length at age and size at maturity. Walters Shoal fish have the lowest weight-at-length, resulting in a significantly lower condition factor, followed by Vema and South Africa. This might be a result of a combination of several factors: The higher temperature in the subtropical environment, which increases metabolic rates and the lower food availability around the seamounts when compared to the South African coast.

The Benguela current system is one of the largest upwelling zones in the world with highly productive waters ${ }^{40}$. The waters around Walters Shoal are oligotrophic and relatively unproductive when compared to the Vema and the South African populations. The observed difference in diet, with piscivorous feeding dominant in the South African fish and crustacean dominated diet around the seamounts supports the explanation for the difference in condition factor. Yellowtail are known to be opportunistic generalist feeders preying on small pelagic fish, crustaceans and squid ${ }^{6,41}$. Small pelagic shoaling species such as sardine (Sardinops sargax) have been reported to be the preferred food source around coastal South Africa in previous studies ${ }^{41}$ and studies suggest that small pelagic fish are of higher nutritional value than demersal fish and crustaceans ${ }^{42}$, the latter two being more prevalent in the diet of the seamount associated samples.

We found significant differences in growth rates, represented as length-at-age, as well as in the length-atmaturation among the three sampling localities. Life history theory assumes adaptive plasticity in age and size at maturity ${ }^{43}$. A trade-off between early maturation, with fewer numbers of offspring with shorter generation length, and later maturation, with increased viability and number of offspring and longer generation length, depending on mortality and access to resources can explain inter- and intra-species variation in these traits ${ }^{44,45}$.

Life history theory predicts trade-offs among growth, maturation and survival ${ }^{45,46}$. Delayed maturity is expected to reduce sub-adult mortality and promotes sustained higher growth performances, as no energy needs to be invested into gonad development. As female body mass and fecundity increase exponentially with size, the advantage of this strategy has been suggested to increase the total egg production capacity (fitness) per spawner ${ }^{47}$. The largest size at maturity found in Walters Shoal yellowtail is in line with the assumptions that maturation can be delayed when offspring viability needs to be enhanced. Walters Shoal, due to the high temperature and oligotrophy of the surrounding waters possibly represents an environment that requires more larval resilience. Vema yellowtail on the other hand matured early and were of the smallest size at age. As food restrictions are unlikely an issue at Vema, the observed pattern might be best explained by increased fishing mortality. Selection for early maturation as well as smaller size at age is thought to be common as fisheries often remove larger fish ${ }^{48}$. Vema has been under heavy fishing pressure since its discovery in 1957 and a population of the spiny lobster Jasus tristani had been fished to local extinction within less than ten years of its discovery ${ }^{49,50}$. Reported catch of yellowtail at Vema by tuna directed commercial fishing vessels is substantial (DEFF, unpublished data) and IUU fishing is thought to be considerable. The fish sampled off South Africa have the largest length at age and intermediate size at 50\% maturity, representing an intermediary position in the trade-off envelope with highest growth due to the most consistent food availability, combined with moderate fishing mortality.

\section{Conclusion}

This study represents one of only a few genetic studies to include samples from these remote seamounts, and is the first for an actively dispersing species. The findings suggest that seamounts can harbour unique populations of commercially fished species distinct from populations associated with continental shelf areas. Differences in life history patterns can largely be explained by phenotypic plasticity related to different environmental conditions and mortality rates, but in combination with the observed genetic differences our findings are in agreement with the 'Island' Hypothesis that yellowtail exist in genetically and phenotypically distinguishable populations. Our findings imply that these populations might need separate assessment, management and conservation.

\section{Methods}

Localities and sampling. Vema seamount $\left(31^{\circ} 41^{\prime} \mathrm{S}, 8^{\circ} 20^{\prime} \mathrm{E}\right)$ is situated in the South Atlantic Ocean approximately $950 \mathrm{~km}$ west of South Africa (Fig. 1). Rising approximately $5000 \mathrm{~m}$ from the surrounding plane, it summits at $22 \mathrm{~m}$ below the surface ${ }^{50}$. Walters Shoal $\left(33^{\circ} 9^{\prime} \mathrm{S}, 43^{\circ} 49^{\prime} \mathrm{E}\right)$ seamount is an isolated seamount found in the Indian Ocean on the Madagascar Ridge. Its location is approximately $1700 \mathrm{~km}$ east of South Africa and 
$850 \mathrm{~km}$ south of Madagascar (Fig. 1). It peaks at $18 \mathrm{~m}$ below the surface of the water with an area of approximately three nautical miles across the shallowest plateau-like part of the seamount ${ }^{5}$. Biogeographically, the area can be described as warm-temperate to subtropical.

The South African temperate coast is influenced by two major current systems, the Benguela, a broad, northward flow along the West Coast that forms the part of the South Atlantic Subtropical Gyre, and the Agulhas, a narrow, warm, swift south-westerly flow along the South African East and South Coast. The two systems are the principal drivers of productivity in the coastal and shelf waters due to upwelling and subsequent plankton blooms and they facilitate the transport of propagules of marine organisms in South African waters ${ }^{51}$.

Samples from Vema were obtained in May 2015 from a pelagic fishery operating occasionally around the seamount. South African yellowtail samples were collected by hook and line fishing during dedicated research outings during austral summer 2011 and 2012 between Dassen Island and Struis Bay. Further genetic samples were obtained from across the South African distributional range of S. lalandi by the South African Department of Environment, Forestry and Fisheries (DEFF) land based observer programme (see fig. 1 in Swart ${ }^{18}$ ). Walters Shoal was sampled during a dedicated, month-long scientific expedition on the RV Algoa in May 2014 when fish were caught by hook and line. Only material from dead animals was used for further analyses. All collections were made under a "permit for the purposes of a scientific investigation or practical experiment in terms of section 79 of the Marine Living Resources Act 1998” issued by the then Department of Agriculture, Forestry and Fisheries, South Africa. All methods were carried out in accordance with relevant guidelines and regulations.

The samples were frozen until processing in the laboratory. Upon defrosting all specimens were measured to the nearest $\mathrm{mm}$ fork length (FL) and total length (TL) and weighed to the nearest gram. Gonads were weighed to the nearest gram and sex and stage of maturation was determined. Stomachs were staged in terms of fullness and weighed to the nearest gram after which the stomach contents were removed and frozen. Both otoliths were removed from the fish, cleaned and kept dry for further processing. In addition, fin clips were taken and stored in $90 \%$ ethanol for subsequent genetic analyses. Information on sample sizes for individual analyses are included in the methodology sections.

DNA extraction. In this study, a total of 201 individuals from South Africa (SA) as well as samples from Vema Seamount $(\mathrm{V}=95)$ and Walters Shoal $(\mathrm{WS}=55)$ were included for microsatellite genotyping. The South African samples comprised Port Elizabeth $(H)=37$, Struis Bay $(G)=55$, Cape Point $(E)=50$, Yzerfontein $(C)=29$ and North Blinder $(B)=30$ ) (Fig. 1, also see fig. 1 in Swart ${ }^{19}$ ). The South African sample sites were included in a previous study investigating the global and regional population structure of the species ${ }^{19}$.

All samples were morphologically identified by the sample collectors and preserved in $95 \%$ ethanol. Genomic DNA extraction was carried out according to the cetyl trimethyl ammonium bromide (CTAB) protocol ${ }^{56,57}$ with minor modification.

PCR amplification and microsatellite genotyping. Six microsatellite markers previously published for $S$. dumerili ${ }^{52}$ were successfully amplified by $\mathrm{PCR}^{53}$ and genotyped in the seven sampling populations (Vema, 5 sampling populations in SA, Walters Shoal). Fragment analysis was performed by capillary electrophoresis on the ABI 3100 automated sequencer. Alleles were scored using MICROSATELIGHT v1 ${ }^{54}$.

Microsatellite genotype analyses. Population diversity. MICRO-CHECKER v2.2.3 was used to test for the presence of null alleles, genotyping errors or other reasons for deviations from HWE, such as heterozygote deficiency ${ }^{55}$.

The population genetic variation for S. lalandi samples was characterised for the two seamounts and the five locations along the South African coastline ${ }^{19}$. Genetic diversity estimates of allele frequencies, observed- (Ho) and unbiased expected heterozygosity (He) were calculated with GENETIX v4.03 ${ }^{56}$. Fstat v2.9.3 $3^{57}$ was used to determine the number of alleles per locus and allelic richness based on a minimum sample size of 29. The inbreeding coefficient, $\mathrm{F}_{\text {IS }}$ was calculated by Fstat and deviations from Hardy-Weinberg equilibrium (HWE) were tested with ARLEQUIN.

The statistical power of the microsatellites to differentiate populations were evaluated and conducted in POWSIM v4.1 ${ }^{19,58}$. This analysis simulates multiple populations that have diverged to predefined true levels of divergence $\left(\mathrm{F}_{\mathrm{ST}}\right)$, and determines the power of a dataset with sample sizes, number of loci, and allele frequencies equal to the present study to differentiate populations. Simulations included true levels of divergence $\left(\mathrm{F}_{\mathrm{ST}}\right)$ that ranged from 0.002 to 0.049 , and significance for both Fisher's exact test and $\chi^{2}$ tests from 1000 replicates. Three simulations were conducted with varying effective population size $(\mathrm{Ne}=100,200,500$ and 2000).

Population structure. Pairwise $\mathrm{F}_{\mathrm{ST}}{ }^{59,60}$ (with Bonferroni correction at the 5\% nominal level) and Nei's (1978) genetic distances ${ }^{61}$ were calculated with GENEPOP $\mathrm{v} 4.0^{62}$ using 1000 permutations. In addition, pairwise $\mathrm{G}^{\prime \prime}{ }_{\mathrm{ST}}{ }^{63}$ and Jost $\mathrm{D}_{\mathrm{EST}}{ }^{64}$ were calculated with GenAlEx 6.5 ${ }^{65,66}$ (999 permutations) between the three main sampling regions. To visualise genotypic partitioning, discriminant analysis of principal components (DAPC) ${ }^{67}$ was carried out using ADEGENET ${ }^{68}$ in $\mathrm{R} 3.0 .2^{69}$. To test for population differentiation, a hierarchical AMOVA was carried out in ARLEQUIN ${ }^{19}$.

Bayesian clustering analysis of populations was performed with STRUCTURE v2.1 ${ }^{70}$. For the analysis on the entire dataset, number of clusters $(\mathrm{K})$ was tested between 1 and 6 . For each $\mathrm{K}, 10$ runs were performed consisting of 10 million Markov chain Monte Carlo (MCMC) iterations with a burn-in of 100,000. K was calculated assuming admixture and correlated allele frequencies ${ }^{18,71}$. The statistic $\Delta \mathrm{K}$ calculated by STRUCTURE HARVESTER $\mathrm{v} 0.6^{72}$ was used to estimate the true number of clusters ${ }^{73}$. For the selected $\mathrm{K}$ value, the individual membership coefficient was assessed to infer the probability of a certain individual belonging to a specific cluster. CLUMPP 
v1.1 was used to average the runs and produce the admixture (Q) matrix ${ }^{74}$. DISTRUCT v1.1 was implemented to visualise the membership coefficients of the individuals within each population ${ }^{75}$.

Life history. Diet. Stomachs (Sample sizes: V=54; $\mathrm{SA}=62$; WS $=56$ ) were defrosted and the contents extracted by opening the stomach and squeezing out the contents. The numbers of stomachs with food present or absent were recorded to determine the coefficient of repletion (percentage of stomachs containing food). Upon visual inspection, the contents were separated into individual components where possible. For the identification of fish, cephalopods and mollusc prey items, the otoliths and beaks and shells were collected, respectively, after initial visual examination of partially digested specimens was deemed inconclusive. Only, crustaceans could be identified from largely complete exoskeletons. Where necessary, specimens were examined under a dissecting microscope and identified to the lowest possible taxon using identification guidebooks and experts. Due to the variation in stomach fullness and regurgitation rates among sites, comparisons involving prey weight such as the index of relative importance for specific prey species were not feasible. The frequency of occurrence (FO) for each prey item was calculated as the number of stomachs that particular prey item was found in divided by the total number of stomachs examined.

Age and growth. All fish sampled (345) were measured to the nearest mm fork length $(F L)$ and weighted to nearest gram. Morphometric relationships were determined by plotting the $F L$ of the fish against their corresponding weights. The values for the growth parameters $a$ and $b$ were determined by log transformation and linear regression of the form:

$$
\log (W)=\log (a)+F L * b
$$

The condition factor $(K)$ was determined as follows ${ }^{76}$ :

$$
K=100 \times W /(F L)^{3}
$$

The majority of specimens (74\%) fell within 500 and $700 \mathrm{~mm}$ size classes, which were representatively sampled for all three locations, whereas smaller fish and very large fish $(>800 \mathrm{~mm})$ were underrepresented in samples from the two seamounts. For appropriate statistical comparison of differences in $K$, a one-way ANOVA (Sample sizes: $\mathrm{V}=57$; $\mathrm{SA}=132$; WS $=56$ ) was therefore only applied to specimens from the representatively sampled 500-700 mm size classes across the three locations.

The right otolith of a pair was used for age determination. Whole otoliths set in black plastic trays were viewed and imaged under a Nikon dissecting microscope at 8-16× magnification with reflected light. Images were taken and three readers examined the samples independently after which the data was collated and compared. The accepted age was the age for which two or three readers were in agreement. As the small sample sizes and the incomplete size spectrum of the samples precluded fitting a meaningful growth model, the sizes of yellowtail with 3 and 4 growth rings (i.e. 3 and 4 years old, $V=31, S A=162, W S=33$ ) were compared among locations by fitting a two-way ANOVA with the covariates Age and Location.

Sex ratio and gonad development. Visual inspection of the gonads provided the sex and the stage of sexual maturity (Sample sizes: $\mathrm{V}=54 ; \mathrm{SA}=51 ; \mathrm{WS}=56$ ). The proportion of sexually mature males and females was determined by considering any individual at stage 2 or higher as mature. The statistical analysis) only included female data due to their higher relevance to spawning output of the populations. The maturity status of each female was transformed into a binary response variable by assigning 0 for immature and 1 for mature or maturing females. Due to the expected binominal distribution of the binary response, a GLM (Generalized Linear Model) with binomial distribution and a logit link function was fitted to test for statistical differences in lengthat-maturity among the three locations, where location was treated as factor. Analogous to an ANOVA, analysis of deviance based on was conducted to test if the factor location explained significant variation in the data as judged by $\chi^{2}$-tests of changes in total deviation explained.

Received: 30 April 2020; Accepted: 14 December 2020

Published online: 11 February 2021

\section{References}

1. Holland, K. N. \& Grubbs, R. D. Fish visitors to seamounts: Tunas and billfish at seamounts. In Seamounts: Ecology, Fisheries and Conservation (eds Pitcher, T. J. et al.) 89-201 (Blackwell Publishing, Oxford, 2007).

2. Pitcher, T. J. et al. Seamounts: Ecology, Fisheries \& Conservation (John Wiley \& Sons, New York, 2008). .

3. Pazmiño, D. A. et al. Strong trans-Pacific break and local conservation units in the Galapagos shark (Carcharhinus galapagensis) revealed by genome-wide cytonuclear markers. Heredity 120, 407-421 (2018).

4. Berrisford, C. D. Biology and zoogeography of Vema Seamount: A report on the first biological collection made on the summit. Trans. R. Soc. S. Afr. 38, 387-398 (1969).

5. Collette, B. B. \& Parin, N. V. Shallow-water fishes of Walters Shoals Madagascar Ridge. Bull. Mar. Sci. 48, 1-22 (1991).

6. Baxter, J. L. A. study of the yellowtail Seriola dorsalis (Gill). State of California department of fish and game. Mol. Biol. Ecol. 110, 96 (1960).

7. Gillanders, B. M., Ferrell, D. J. \& Andrew, N. L. Size at maturity and seasonal changes in gonad activity of yellowtail kingfish (Seriola lalandi; Carangidae) in New South Wales, Australia, New Zealand. Mol. Biol. Ecol. 33, 457-468 (1999).

8. Shiraishi, T., Ohshimo, S. \& Yukami, R. Age, growth and reproductive characteristics of gold striped amberjack Seriola lalandi in the waters off western Kyushu Japan. Mol. Biol. Ecol. 44, 117-127 (2010). 
9. Miranda, I. T. \& Peet, C. Farmed Yellowtail Seriola spp. Japan and Australia. Final Report, October 22, 2008 (2008)

10. Griffiths, M. H. Long-trends in catch and effort of commercial linefish off South Africa's Cape Province: Snapshots of the 20th century. S. Afr. J. Marine Sci. 22, 81-110 (2000).

11. Kerwath and Wilke. Yellowtail (Seriola lalandi). In: Southern African Marine Linefish Species Profiles (ed. Mann BQ, Special Publication, Oceanographic Research Institute, Durban 9, 23-24, 2013).

12. Penney, A. The southern Cape yellowtail fishery-a research perspective and preliminary results. Internal Report, Sea Fisheries Research Institute South Africa 08: 19 pp (1982)

13. Wilke, C. G. \& Griffiths, M. H. Movement patterns of offshore linefish based on tagging results. SANCOR Occ. Rep. 5, 98-107 (1999).

14. Gillanders, B. M., Ferrell, D. J. \& Andrew, N. L. Estimates of movement and life-history parameters of yellowtail kingfish (Seriola lalandi): How useful are data from a cooperative tagging programme?. Mol. Biol. Ecol. 52, 179-192 (2001).

15. Holdsworth, J. C., McKenzie, J. R., Walsh, C., van der Straten, K.M. \& Ó Maolagáin, C. Catch-at-age of yellowtail kingfish (Seriola lalandi) caught by recreational fishers in KIN 1, New Zealand. New Zealand Fisheries Assessment Report 2013/3. 31 p. (2013).

16. Dunn, K. The diet, reproductive biology age and growth of yellowtail, Seriola lalandi, in South Africa. Unpublished MSc thesis, University of Cape Town (2014).

17. Gilchrist, J. D. F. The development of the South African fishes Part-1. Mar. Investig. South Africa 2, 181-201 (1903).

18. Martinez-Takeshita, N. et al. A tale of three tails: Cryptic speciation in a globally distributed marine fish of the genus Seriola. Copeia 103, 357-368 (2015).

19. Swart, B. L., Bester-van der Merwe, A. E., Kerwath, S. E. \& Roodt-Wilding, R. Phylogeography of the pelagic fish Seriola lalandi at different scales: confirmation of interocean population structure and evaluation of southern African genetic diversity. Afr. J. Mar. Sci. 38, 513-524 (2016).

20. Rogers, A. D. The biology of seamounts. Adv. Mar. Biol. 30, 304-360 (1994).

21. Samadi, S. et al. Seamount endemism questioned by the geographical distribution and population genetic structure of marine invertebrates. Mar. Biol. 149, 1463-1475 (2006).

22. Clark, M. R. et al. The ecology of seamounts: Structure, function, and human impacts. Annu. Rev. Mar. Sci. 2, 253-278 (2010).

23. Cho, W. \& Shank, T. M. Incongruent patterns of genetic connectivity among four ophiuroid species with differing coral host specificity on North Atlantic seamounts. Mar. Ecol. 31, 121-143 (2010).

24. Shank, T. M. Deep-ocean laboratories of faunal connectivity, evolution, and endemism. Oceanography 23, 108-122 (2010).

25. Bradbury, I. R., Laurel, B., Snelgrove, P. V. R., Bentzen, P. \& Campana, S. E. Global patterns in marine dispersal estimates: the influence of geography, taxonomic category and life history. Proc. R. Soc. Lond. Ser. B. Biol. Sci. 275, 1803-1809 (2008).

26. Diggles, B. K. Import risk assessment: juvenile yellowtail kingfish (Seriola lalandi) from Spencer Gulf aquaculture, South Australia. Client Report No. WLG 2002/03. National Institute of Water and Atmospheric Research (NIWA) Ltd, Kilbirnie, Wellington, New Zealand (2002).

27. Bang, N. D. Dynamic interpretations of a detailed Surface temperature chart of the Agulhas Current retroflexion and fragmentation area. S. Afr. Geogr. J. 52, 67-76 (1970).

28. Lutjeharms, J. R. E. \& Gordon, A. L. Shedding of an Agulhas Ring observed at sea. Nat. Lond. 325, 138-140 (1987).

29. Duncombe Rae, C. M. Agulhas retroflection rings in the South Atlantic Ocean: An overview. S. Afr. J. Marine Sci. 11, 327-344 (1991).

30. Lutjeharms, J. R. E. The exchange of water between the South Indian and the South Atlantic. In The South Atlantic: Present and Past Circulation (eds Wefer, G. et al.) 125-162 (Springer, Berlin, 1996).

31. Martin, A. P., Humphreys, R. \& Palumbi, S. R. Population genetic-structure of the armorhead, Pseudopentaceros wheeleri, in the North Pacific Ocean: Application of the polymerase chain reaction to fisheries problems. Can. J. Fish. Aquat. Sci. 49, 2386-2391 (1992).

32. Hoarau, G. \& Borsa, P. Extensive gene flow within sibling species in the deep-sea fish Beryx splendens. CR Acad. Sci. III Vie 323, 315-325 (2000).

33. Smith, P. J. et al. Genetic and meristic variation in black and smooth oreos in the New Zealand EEZ. Mol. Biol. Ecol. 36, 737-750 (2002).

34. Levy-Hartmann, L., Roussel, V., Letourneur, Y. \& Sellos, D. Y. Global and New Caledonian patterns of population genetic variation in the deep-sea splendid alfonsino, Beryx splendens, inferred from mtDNA. Genetica 139, 1349-1365 (2011).

35. Catarino, D., Stefanni, S. \& Menezes, G. M. Size distribution and genetic diversity of the offshore rockfish (Pontinus kuhlii) from three Atlantic archipelagos and seamounts. Deep-Sea Res. Pt. II(98), 160-169 (2013).

36. Varela, A. I., Ritchie, P. A. \& Smith, P. J. Global genetic population structure in the commercially exploited deep-sea teleost orange roughy (Hoplostethus atlanticus) based on microsatellite DNA analyses. Fish. Res. 140, 83-90 (2013).

37. Aboim, M. A., Menezes, G. M., Schlitt, T. \& Rogers, A. D. Genetic structure and history of populations of the deep-sea fish Helicolenus dactylopterus (Delaroche, 1809) inferred from mtDNA sequence analysis. Mol. Ecol. 14, 1343-1354 (2005).

38. Stockley, B. M., Menezes, G., Pinho, M. R. \& Rogers, A. D. Genetic population structure of the black-spot sea bream (Pagellus bogaraveo) from the NE Atlantic. Mar. Biol. 146, 793-804 (2005).

39. Rogers, A. D., Morley, S., Fitzcharles, E., Jarvis, K. \& Belchier, M. Genetic structure of Patagonian toothfish (Dissostichus eleginoides) populations on the Patagonian Shelf and Atlantic and western Indian Ocean sectors of the Southern Ocean. Mar. Biol. 149, 915-924 (2006).

40. Hutchings, L. et al. The Benguela Current: An ecosystem of four components. Progr. Oceanogr. 83(1-4), 15-32. https://doi. org/10.1016/j.pocean.2009.07.046 (2009).

41. Nepgen, C. S. Diet of predatory and reef fish in False Bay and possible effects of pelagic purse-seining on their food supply. Mol. Biol. Ecol. 16, 75-93 (1982).

42. Massias, A. \& Becker, P. H. Nutritive value of food and growth in Common Tern Sterna hirundo chicks. Ornis Scand. 1, 187-194 (1990).

43. Stearns, S. C. The Evolution of Life Histories 249 (Oxford University Press, New York, 1992).

44. Stearns, S. C. \& Koella, J. C. The evolution of phenotypic plasticity in life-history traits: Predictions of reaction norms for age and size at maturity. Evolution 40, 893-913 (1986).

45. Shuter, B. J. et al. Optimal life histories and food web position: Linkages among somatic growth, reproductive investment, and mortality. Can. J. Fish. Aquat. Sci. 62, 738-746 (2005).

46. Jensen, A. Beverton and Holt life history invariants result from optimal trade-off of reproduction and survival. Can. J. Fish. Aquat. Sci. 53, 820-822 (1996).

47. Winemiller, K. O. \& Rose, K. A. Patterns of life-history diversification in North American fishes: Implications for population regulation. Can. J. Fish. Aquat. Sci. 49, 2196-2218 (1992).

48. Law, R. Fishing, selection, and phenotypic evolution. ICES J. Mar. Sci. 57, 659-668 (2000).

49. Heydorn, A. E. F. Research on the Vema Seamount. Afr. Ship. News Fish. Ind. Rev 12, 79-83 (1967).

50. Bergstad, Odd Aksel, Åge Sigurd Høines, Roberto Sarralde, G. Campanis, M. Gil, Fran Ramil, E. Maletzky, E. Mostarda, Larvika Singh, and M. A. António. "Bathymetry, substrate and fishing areas of Southeast Atlantic high-seas seamounts." African J. of Marine Science 41, no. 1 (2019): 11-28. 
51. Hutchings, L. et al. Spawning on the edge: Spawning grounds and nursery areas around the southern African coastline. Mol. Biol. Ecol. 53, 307-318 (2002).

52. Doyle, J. J. \& Doyle, J. L. A rapid DNA isolation procedure for small quantities of fresh leaf tissue. Phytochem. Bull. 19, 11-15 (1987).

53. Doyle, J. J. \& Doyle, J. L. Isolation of plant DNA from fresh tissue. Focus 12, 13-15 (1990).

54. Palero, F., González-Candelas, F. \& Pascual, M. MICROSATELIGHT-Pipeline to expedite microsatellite analysis. J. Hered. 102, $247-249(2011)$.

55. Van Oosterhout, C., Hutchison, W. F., Shipley, P. \& Wills, D. P. M. Micro-Checker: Software for identifying and correcting genotyping errors in microsatellite data. Mol. Ecol. 4, 535-538 (2004).

56. Belkhir, K., Borsa, P., Goudet, J., Chikhi, L. \& Bonhomme, F. GENETIX, logiciel sous Window TM pour la génétique des populations. Laboratoire Génome et Populations, Montpellier, France. (2000) http://kimura.univ-montp2.fr/genetix/

57. Goudet, J. FSTAT, a Program to estimate and test gene diversities and fixation indices version 2.9.3. (2001). http://www.unil.ch/ izea/softwares/fstat.html

58. Ryman, N. \& Palm, S. POWSIM: A computer program for assessing statistical power when testing for genetic differentiation. Mol. Ecol. 6, 600-602 (2006).

59. Weir, B. S. \& Cockerham, C. C. Estimating F-statistics for the analysis of population structure. Evolution 38, 1358-1370 (1984).

60. Holsinger, K. E. \& Weir, B. S. Genetics in geographically structured populations: Defining, estimating and interpreting FST. Nat. Rev. Genet. 10, 639-650 (2009).

61. Nei, M. Estimation of average heterozygosity and genetic distance from a small number of individuals. Genetics 89, 583-659 (1978).

62. Rousset, F. Genepop'007: A complete re-implementation of the genepop software for Windows and Linux. Mol. Ecol. Resour. 8, 103-106 (2008).

63. Meirmans, P. G. \& Hedrick, P. W. Assessing population structure: FST and related measures. Mol. Ecol. Resourc. 11, 5-18 (2011).

64. Jost, L. GST and its relatives do not measure differentiation. Mol. Ecol. 17, 4015-4026 (2008).

65. Peakall, R. \& Smouse, P. E. GenAlEx 6.5: genetic analysis in Excel. Population genetic software for teaching and research-an update. Bioinformatics 28, 2537-2539 (2012).

66. Peakall, R. \& Smouse, P. E. GenAlEx 6: Genetic analysis in Excel. Population genetic software for teaching and research. Mol. Ecol. Notes. 6, 288-295 (2006).

67. Jombart, T., Devillard, S. \& Balloux, F. Discriminant analysis of principal components: A new method for the analysis of genetically structured populations. BMC Genet. 11, 94 (2010).

68. Jombart, T. Adegenet: A R package for the multivariate analysis of genetic markers. Bioinformatics 24, 1403-1405 (2008).

69. R Core Team. R: a language and environment for statistical computing. Vienna: R Foundation for Statistical Computing. (2013)

70. Pritchard, J. K., Stephens, M. \& Donnelly, P. Inference of population structure using multilocus genotype data. Genetics 155, 945-959 (2000).

71. Bester-van der Merwe, A. E. et al. Population genetics of Southern Hemisphere tope shark (Galeorhinus galeus): Intercontinental divergence and constrained gene flow at different geographical scales. PLoS ONE 12(9), e0184481 (2017).

72. Earl, D. A. \& Vonholdt, B. M. STRUCTURE HARVESTER: A website and program for visualizing STRUCTURE output and implementing the Evanno method. Conserv. Genet. Resour. 4(2), 359-361 (2012).

73. Evanno, G., Regnaut, S. \& Goudet, J. Detecting the number of clusters of individuals using the software STRUCTURE: A simulation study. Mol. Ecol. 14, 2611-2620 (2005).

74. Jakobsson, M. \& Rosenberg, N. A. CLUMPP: A cluster matching and permutation program for dealing with label switching and multimodality in analysis of population structure. Bioinformatics 23, 1801-1806 (2007).

75. Rosenberg, N. A. DISTRUCT: a program for the graphical display of population structure. Mol. Ecol. Notes 4, 137-138 (2004).

76. Froese, B. R. Cube law, condition factor and weight-length relationships: History, meta-analysis and recommendations. J. Appl. Ichthyol. 22, 241-253 (2006).

\section{Acknowledgements}

Kieron Dunn is acknowledged for his contribution to collection of South African samples. We would like to thank the officers and crew of the RV Algoa who participated in the expedition to Walters Shoal for enabling the sample collection. This research was supported by the NRF ACEP (Walters Shoal grant number UGN 92613) and the Department of Environment, Forestry and Fisheries (DEFF).

\section{Author contributions}

S.E.K. conceptualized the study, collected samples, conducted life history analyses and data interpretation and drafted the manuscript. R.R.W. and A.E.B.M. conducted genetic data interpretation and drafted the manuscript. B.L.S. conducted the genetic data analyses, and drafted the manuscript. H.W. conducted life history analysis. W.W. conducted diet analyses. S.L. conducted age and growth analysis and data interpretation. A.G. and S.S. conducted life history and diet analyses. T.S. conceptualized the study, collected samples and drafted the manuscript. C.W. collected samples and conducted life history analyses. All authors contributed to drafting and editing of the manuscript.

\section{Funding}

We acknowledge financial support through the African Coelacanth Ecology Programme (ACEP) and the Department of Environment, Forestry and Fisheries (DEFF).

\section{Competing interests}

The authors declare no competing interests.

\section{Additional information}

Supplementary Information The online version contains supplementary material available at https://doi. org/10.1038/s41598-021-82501-z.

Correspondence and requests for materials should be addressed to S.K.

Reprints and permissions information is available at www.nature.com/reprints. 
Publisher's note Springer Nature remains neutral with regard to jurisdictional claims in published maps and institutional affiliations.

(c) (i) Open Access This article is licensed under a Creative Commons Attribution 4.0 International License, which permits use, sharing, adaptation, distribution and reproduction in any medium or format, as long as you give appropriate credit to the original author(s) and the source, provide a link to the Creative Commons licence, and indicate if changes were made. The images or other third party material in this article are included in the article's Creative Commons licence, unless indicated otherwise in a credit line to the material. If material is not included in the article's Creative Commons licence and your intended use is not permitted by statutory regulation or exceeds the permitted use, you will need to obtain permission directly from the copyright holder. To view a copy of this licence, visit http://creativecommons.org/licenses/by/4.0/.

(C) The Author(s) 2021 